\author{
Najah M.L. Al Maimuri \\ Al Furat Al Awsat Technical \\ University, Kufa, Iraq. \\ najahml@yahoo.com
}

\section{Arkan R. Ali \\ Al Furat Al Awsat Technical University, Kufa, Iraq.}

\section{Abdulhadi M. Al-Sa'adi \\ Al-Mustaqbal Unversity College, Hillah, Iraq. \\ dbdalhadyalsdy@gmail.com}

\section{Mohammed K. Abed}

Al Furat Al Awsat Technical University, Kufa, Iraq.

Received on: 11/07/2018

Accepted on: 10/01/2019

Published online:25/06/2019

\title{
Hydrogeologic Sustainability and Mitigation of Shallow Groundwater against High Saline and Chemical Pollutants
}

Abstract- A hydrogeologic study has been adopted to conceptualize the concepts of groundwater levels lowering in swamped area of Tyass, middle of Iraq. 2D dimensional groundwater model and, mitigation model has been used to mitigate the aquifer against high salinity and chemical pollutants by the mitigation theory of heterogeneous subsurface media, which depends upon physical and mathematical derivation, evaluation of chemical pollutants and total dissolved salts (TDS) of subsurface water before and after mitigation process. The water table level was lowered up to $2.43 \mathrm{~m}$ at the center of a pumping well of abstraction discharge $\left(400 \mathrm{~m}^{3} /\right.$ day) obtained after 2755days in steady state. The ions concentrations of iron (Fe), zinc $(\mathrm{Zn})$, mercury $(\mathrm{Cu})$, cadmium $(\mathrm{Cd})$, lead $(\mathrm{Pb})$ and TDS in groundwater of $0.4,3.25,1.15,0.004,0.033 \mathrm{mg} /$ liter and 7000ppm respectively were reduced to less than the allowable limits according to WHO of $0.3,3,1$, $0.003,0.01 \mathrm{mg} /$ liter, $1200 \mathrm{ppm}$ respectively by adding $0.2 \mathrm{WD}$ of fresh water from Hillah river and using maximum no. of pumping wells of (19 at April) after 240 months. The mitigation period was reduced to 120 months when the addition of solvent volume was doubled. Mitigation process in heterogeneous against high saline levels and chemical pollutants has been proven a good tool for the rehabilitation of polluted aquifers.

Keywords- Groundwater modeling, Mitigation model, Chemical pollutants, Saline level How to cite this article: N.M.L. Al Maimuri, A.R. Ali and A.M. Al-Sa'adi, "Hydrogeologic Sustainability and Mitigation of Shallow
Groundwater Aquifers against High Saline and Chemical Pollutants," Engineering and Technology Journal, Vol. 37, Part C, No. 2, pp. 303$310,2019$.

\section{Introduction}

In arid and Semi-arid regions, the problem of high salination and concentration of chemical pollutants in unconfined bearing layers is predominantly common, especially wherever groundwater flow motion is slow and the replenishment process is inactive. This high concentration of chemical pollutants and salination is originated due to a chemical rock decomposition into the groundwater and active potential evapotranspiration. Many attempts have been performed in this aspect to understand minerals and pollutants transportation and concentration rise in porous media. No direct and related studies in this concept but close is found such as [1] outlined that a good understanding of land-use can generate guidelines for sustainable groundwater management and appropriate remediation measures could then be suggested taking into account land-use and percolation potential. Operational measures can be suggested to mitigate groundwater quality. Two study areas were undertaken in different regions of Israel's coastal aquifer, Erez-Shiqma and Ra'anana areas. [2] presented the results of lab and field work in the Fortaleza Metropolitan Region, in the state of Ceará, Brazil, for land degradation. Environmental indicators Classification for each drainage basin was in three levels; low, intermediate and high. They described the types of degradations as coastal erosion, gravitational motions of masses, dune movements, erosion, sedimentation, GW contamination pollution, landfills in unspecified locations, caves and abandoned mines of aggregates exploitation and work in swamps.

[3] demonstrated that a saturated zone denitrification in shallow groundwater with ${ }^{3} \mathrm{H} /{ }^{3} \mathrm{He}$ apparent ages of $<35$ years at two central California dairies was achieved. Animal feeding operation was the main source of nitrate to groundwater. Denitrification is found anoxic zone $5 \mathrm{~m}$ below the water table in one site and at a second dairy, site occurs near the water table. [4] 
indicates that Multivariate, deterministic and stochastic methods were used to assess nitrate and pesticides levels in shallow groundwater of Mondego river, Portugal, where agricultural landuse was dominant. Nitrate risk exceeding $50 \mathrm{mg} / 1$. Denitrification is found important attenuation process as well as dilution by surface water. Crop type and irrigation source were very effective on nitrate contamination potential on GW. Total concentrations of pesticide compounds above $0.5 \mu \mathrm{g} / 1$ are observed in $32 \%$ of water samples, with a maximum value of $16.09 \mu \mathrm{g} / \mathrm{l}$.

[5] outlined that water quality is a major challenge that human health faced in the twentyfirst century. They assessed groups water contamination, approaches of water resources mitigation, particularly in organics and micropollutants including toxic metal and metalloids.

[6] presented a probability model based upon the 3D quaternary formation of Delta Red River. They indicated that $\sim 7$ million delta inhabitants use a polluted GW with toxic elements, including manganese, selenium, and barium. Probability analysis and arsenic concentrations measurements indicate a reduction in arsenic-enriched waters from Holocene to naturally uncontaminated Pleistocene aquifers because of $>100$ years of GW abstraction. They warned to the vertical arsenic migration induced by large-scale pumping from deep uncontaminated aquifer underlying high arsenic aquifers.

[7] stated that the fast-growing industrial city of Nagpur, India, experienced a rapid increasing in drinking groundwater. Their geochemical study comprehended 47 water samples collected from the shallow aquifer of the city and chemical tests are carried out for $\mathrm{Ca}^{2+}, \mathrm{Mg}^{2+}, \mathrm{Na}^{+}, \mathrm{K}^{+}, \mathrm{CO}_{2}^{-}$, $\mathrm{HCO}_{3}, \mathrm{Cl}^{-}, \mathrm{SO}_{2}{ }^{-}$and $\mathrm{NO}_{3}^{-}$are carried out. The Piper diagram identifies that $\mathrm{Ca}-\mathrm{HCO}_{3}-\mathrm{Cl}$ and mixed $\mathrm{Ca}-\mathrm{Na}-\mathrm{HCO}_{3}-\mathrm{Cl}$ prevails. It was concluded that silicate rock and anthropogenic activities are the main sources of the forgoing ions compositions with the highest nitrate concentration of $411 \mathrm{mg} / \mathrm{l}$.

[8] considered the hydrogeologic dilution of Hashymia aquifer by using a dilution process against high concentration rise. The convectiondispersion phenomena are well satisfied and two remediation scenarios were issued.

[9] studied a contaminant transport in the subsurface aquifer of Hashymia region in Iraq. The current research adopted and developed a theory of mitigation in unconfined hydrogeologic mediums wherever and whenever high salination or chemical and biological contamination have been encountered. In such a scientific context, aquifer GW attenuation becomes an efficient tool to dilute GW storage. This process may be taken several faces including chemicals (denitrification, releasing of radiochemical minerals such as ${ }^{222}$ Radon releasing into the air) or Hydrogeologic dilution of unfavorable minerals and TDS by freshwater.

The mitigation process may be naturally occurred in nature by different phenomena such as denitrification of high nitrate groundwater, releasing of radiochemical minerals like radon released into the air and hydrogeologic dilution of unfavorable minerals and TDS by freshwater.

The current research adopted and developed a theory of mitigation in hydrogeologic mediums wherever high salination, chemical and biological contaminations have been encountered. The water table levels of Tyass are lower up to $2.43 \mathrm{~m}$ and an attenuation process was used to reduce the concentrations of the most hazardous minerals in the groundwater including $\mathrm{Fe}, \mathrm{Zn}, \mathrm{Cu}, \mathrm{Cd}, \mathrm{Pb}$ and total dissolved salts (TDS) with concentrations of $0.4,3.25,1.15,0.004,0.033 \mathrm{mg} / 1$ and $7000 \mathrm{ppm}$ to $0.1,1.02,0.23,00.14,0.0021 \mathrm{mg} / 1$ and $500 \mathrm{ppm}$ respectively during a period of time equals 240months. Correspondingly, the mitigation process occasionally may be a suitable technique to attenuating aquifers of high saline and pollutant concentrations.

Due to the construction of a new branch of Hillah River and originating of Tyass Island, the river water correspondingly raised groundwater levels sometimes higher than ground surface level (GSL). Because of area flooding, people migrate their lands and water authority unspecified irrigation water allocation and leaving the area uncultivated. This problem continued less than 10 years, causing many subsurface environmental problems such as soil salination and increase in unfavorable chemical pollutants, including some heavy metals like Iron $(\mathrm{Fe})$ and lead $(\mathrm{Pb})$ in soil.

\section{Materials and Methods}

\section{Geography and geology}

The unconfined bearing water layer of $6.27 \mathrm{~km}^{2}$ of Tyass area in the middle of Iraq is bounded between longitudes $44^{\circ} 41^{\prime} 42^{\prime \prime}-44^{\circ} 46^{\prime}$ and latitudes $32^{\circ} 21^{\prime}-32^{\circ} 25^{\prime}$ and surrounded by two diverted branches of Hillah River Figure 1. In general, the area seems to be flat with $25 \mathrm{~m}$ above sea level (asl). 


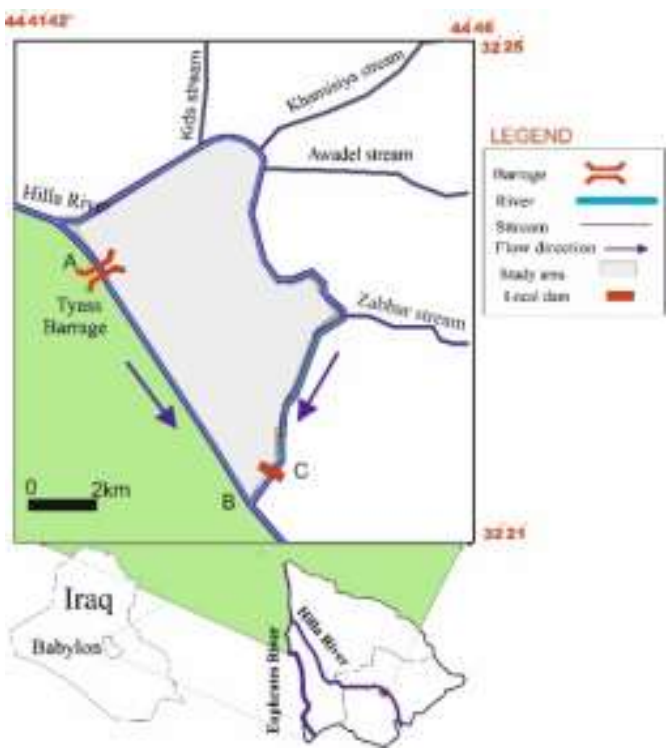

Figure 1: Location map, after [7]

Geologically, the area is covered with quaternary unconsolidated deposits that usually consist of finer grained than the underlying pebbly sandstone [10]. Quaternary deposits are represented by flood plain sediments of the Euphrates River. These deposits comprehend clay; silt and sand with deposits of gypsum in addition to depression fill sediments, these deposits accumulated because of the floods of the Euphrates River, generally consisting of fine sand layers, silt and silt loam, [11]. In general, recent sediments within the area consist of succession layers of mud, sand, and shale with a little number of gravels in deeper layers. High saline levels certainly produce bad environment impacts for future unconfined aquifer sustainability and low endurance plants health for exaggerated saline levels and unfavorable minerals. Correspondingly, hydrologic mitigation for aquifer salination and contamination becomes evitable and needs to be considered and developed.

\section{Groundwater model development}

A groundwater model of [12] was developed to fit the natural groundwater flow pattern of the unconfined aquifer. The model domain was discretized into $36 * 46$ meshes in $\mathrm{X}$-axis and $\mathrm{Y}$ axis, respectively, as in Figure 2. The recovery transmissivity analysis [13] is shown in Figure 3. The average transmissivity was found to be $200 \mathrm{~m}^{2} /$ day. The specific yield is chosen to be $(0.2)$ of similar geologic formation, as outlined by [14]. Local field double ring infiltrometer measurements showed that the infiltration potential was found to be $(0.2 \mathrm{~mm} /$ day $)$ and most the infiltrated water reaching the unconfined aquifer mainly comes from irrigation water. All the foregoing properties were included in the model defaults and input data files and adjusted during the model calibration

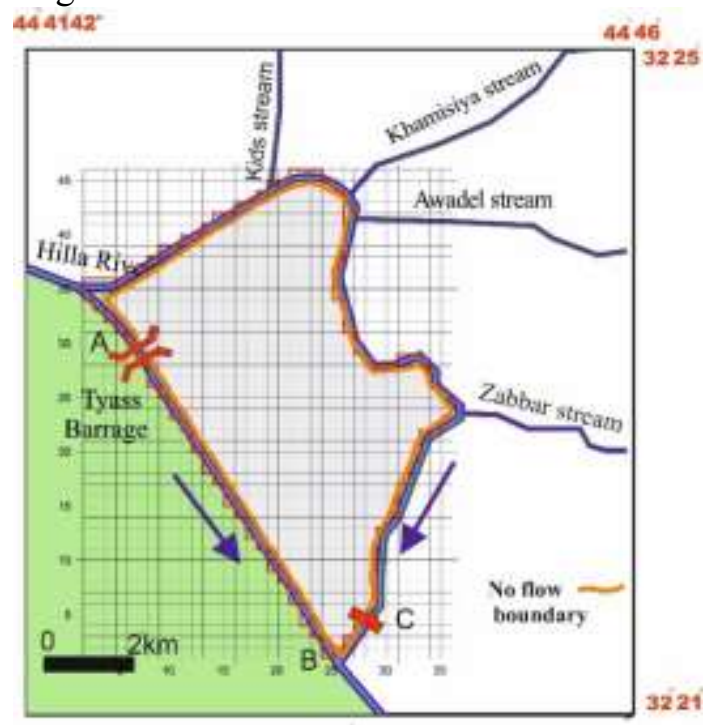

Figure 2: Plain view of a no flow barrier and meshes discretization

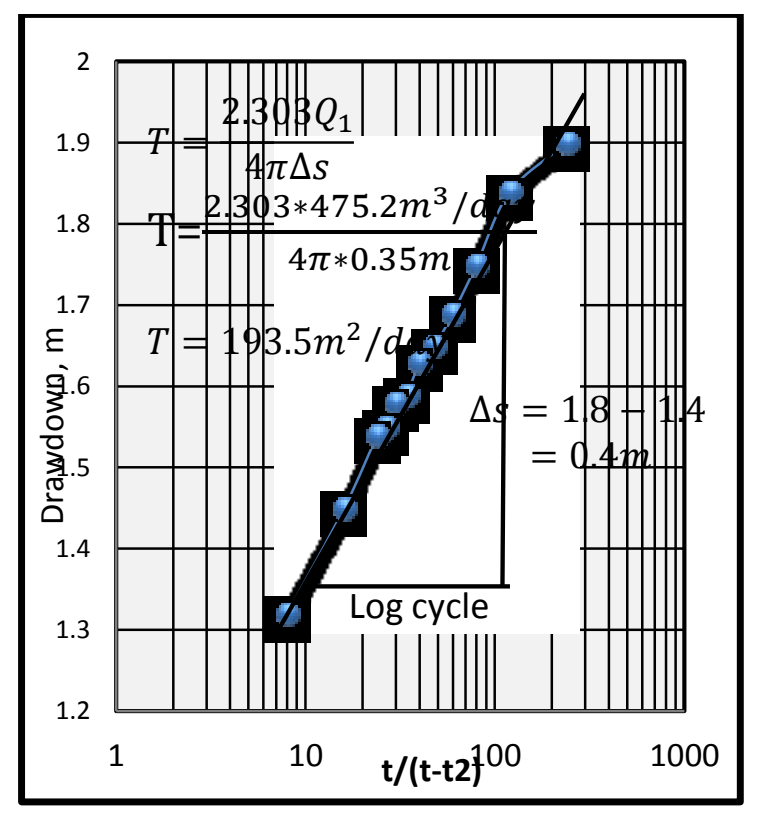

Figure 3: Recovery of pumping test analysis

\section{Aquifer geometry}

Briefly, it is found that the average aquifer bottom level is $20 \mathrm{~m}$ above sea level (asl), whereas the natural groundwater levels are presented in Figure 4. 


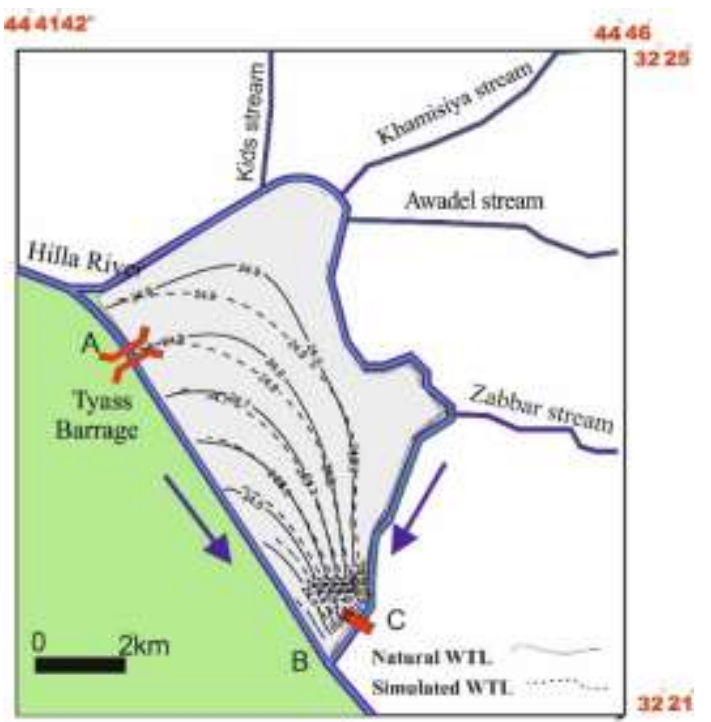

Figure 4: Natural \& simulated groundwater levels, in ( $\mathrm{m}$ asl)

\section{Model calibration and verification}

The model was calibrated and verified before any environmental applications. After the model program has been run for time enough to reach a steady state condition, the simulated water table levels are compared with the natural values. The calibration process shows a matching between the natural and simulated groundwater levels of maximum difference less than $10 \%$, Figure 4 .

To verify the model, a pumping well of (400 $\mathrm{m}^{3} /$ day) productivity was setup in a location shown in Figure 5 to evaluate both a safe yield (SY) and transmissivity of existing wells. The figure also presents the resulting contour maps for both groundwater levels and drawdowns. It is indicated that $\left(400 \mathrm{~m}^{3} /\right.$ day $)$ is a safe yield that can be exploited within a single node to produce a drawdown of $(2.43 \mathrm{~m})$ at the center of pumping well along section (a-b). The resulting cone of depression at a steady state condition is shown in Figure 6.

The time-drawdown variation curves at the locations of $100 \mathrm{~m}$ beyond the pumping well location, respectively are shown in Figure 7. The maximum drawdown of $1.38 \mathrm{~m}$ has been obtained after 2755day, respectively, as presented in Figures $(6 \& 7)$.

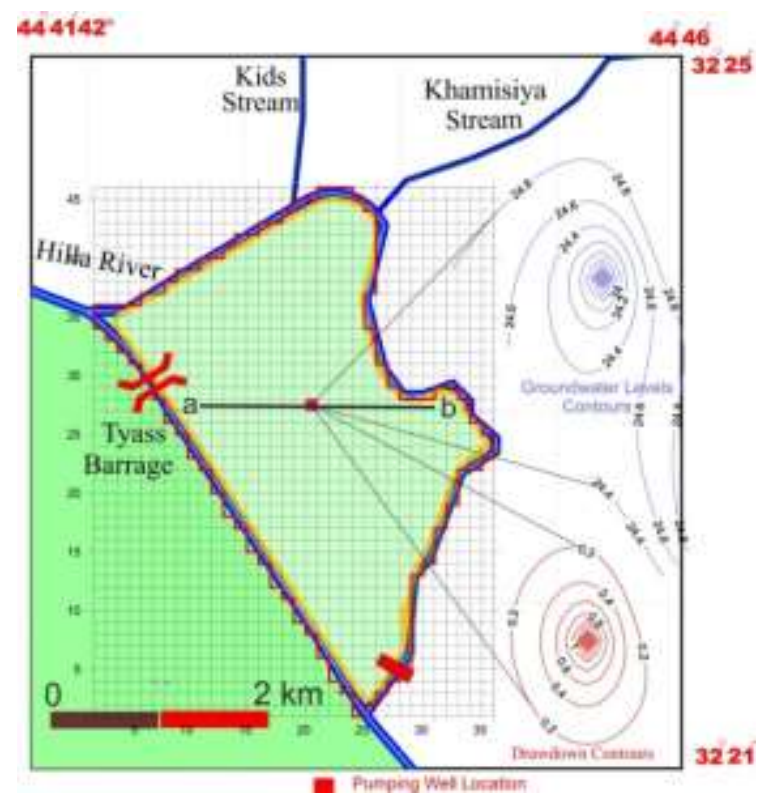

Figure 5: Pumping well location, groundwater levels and drawdown contours

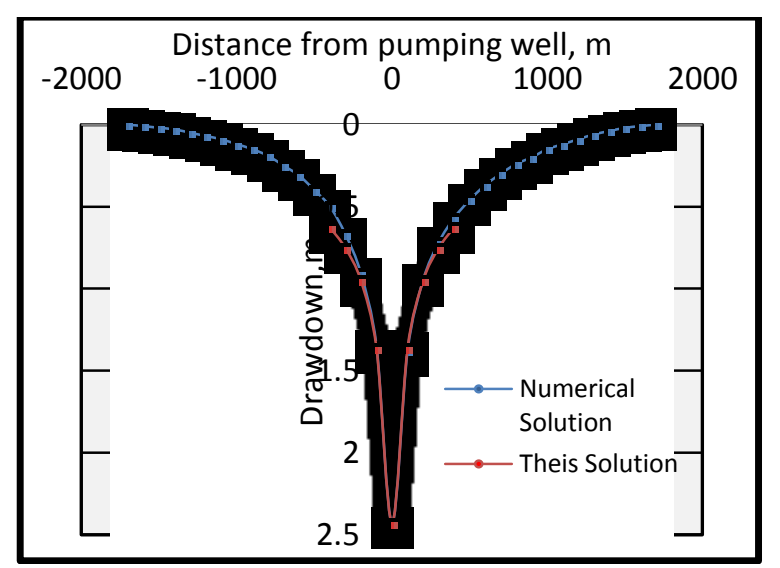

Figure 6: Distance-Drawdown comparison of Theis \& numerical solutions along the section (a-a)

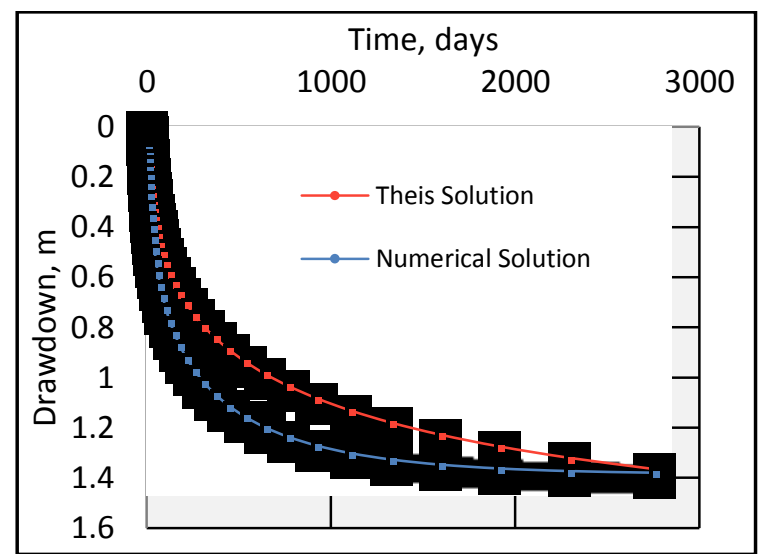

Figure 7: Time-Drawdown curves of the numerical and Theis solutions

\section{a. Mitigation concept development}

Mitigation process in heterogeneous media against high saline concentrations and other types of contamination as radiological elements and 
heavy metals needs preapprehension of the physical and mathematical basis of mitigation.

\section{Theoretical background}

Let a solute of concentration $\left(C_{\Delta}\right)$ in $\mathrm{mg} /$ liter and volume $(\Delta V)$ in liters is added to a solution volume $\left(V_{1}\right)$ with a concentration of $\left(C_{1}\right)$, Figure 8 . The resulting volume is $\left(V_{2}\right)$ with concentration $\left(C_{2}\right)$. Moreover, the conservation of mass requires that:

solvent mass ${ }_{1}=$ solvent mass m $_{2}$

But incethe mass of the solvent in solution $=$ $c$. Therefore Eq.(1) becomes

$c_{2} v_{2}=\Delta v c_{\Delta}+c_{1} v_{1}$

But:

$v_{2}=v_{1}+\Delta v$

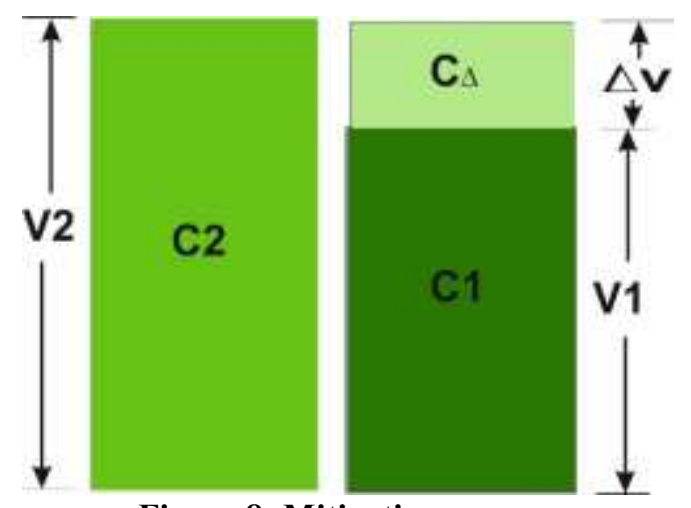

Figure 8: Mitigating process

Combining of Eq.2 and Eq.3 offers a mitigation model in heterogeneous media:

$c_{2}=\frac{c_{1} v_{1}+c_{\Delta} \Delta v}{\left(v_{1}+\Delta_{v}\right)}$

(4)

By Eq. 4 one can estimate concentration $\left(c_{2}\right)$ of pollutant in the water-bearing layer after adding $(\Delta v)$ of fresh $\left(c_{\Delta}=0\right)$ water or even with the concentration $\left(c_{\Delta} \neq 0\right)$ to the original volume $\left(v_{1}\right)$ with concentration $\left(c_{1}\right)$.

\section{Groundwater chemistry}

The sustainability of groundwater category of Tyass area constantly required an investigation of the accumulated chemical compositions of most effective minerals originating from the permanent interflow of Hillah River and potential evapotranspiration. Briefly, the most effective mineral, including $\mathrm{Fe}, \mathrm{Zn}, \mathrm{Cu}, \mathrm{Cd}, \mathrm{Pb}$, and TDS, were measured and listed in Table 1 . The minerals represent not all existing minerals but the dominant in the groundwater environment of Tyass. In general, the results reveal that all minerals concentration exceeds the allowable limits.
Table 1: Average concentration of most effective ions

\begin{tabular}{|c|c|c|c|c|}
\hline $\bar{\bigotimes}_{\mathscr{N}}$ & $\underset{\infty}{E}$. & 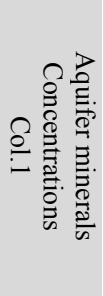 & 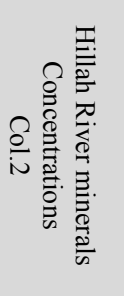 & 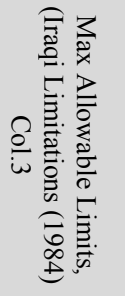 \\
\hline $\mathrm{Fe}$ & \multirow{5}{*}{ 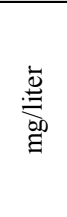 } & 0.40 & 0.1 & 0.30 \\
\hline $\mathrm{Zn}$ & & 3.25 & 1.02 & 3.00 \\
\hline $\mathrm{Cu}$ & & 1.15 & 0.23 & 1.00 \\
\hline $\mathrm{Cd}$ & & 0.004 & 0.0014 & 0.003 \\
\hline $\mathrm{Pb}$ & & 0.033 & 0.0021 & 0.01 \\
\hline TDS & ppm & 7000 & 500 & $\begin{array}{c}1200 \\
\text { Sensitive } \\
\text { plants }\end{array}$ \\
\hline
\end{tabular}

\section{Groundwater lowering}

Tyass area, as shown in Figure 9, was swamped and needs to groundwater lowering. It was decided to use the pumping well shown in Figure 5 for this purpose and found that a pumping discharge of $\left(400 \mathrm{~m}^{3} /\right.$ day $)$ is enough to lower the groundwater levels $2.43 \mathrm{~m}$ at the center of the area.

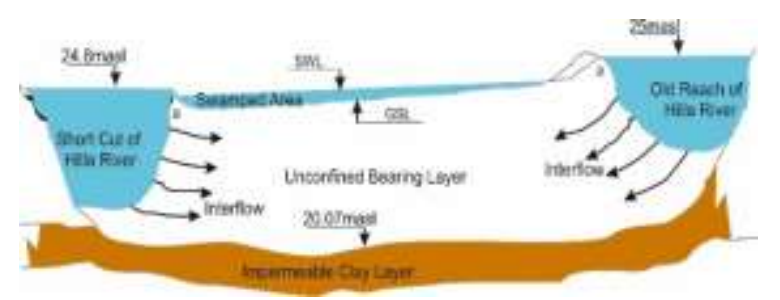

Figure 9: Cross section a-a (pointed out in Fig.5), [14]

\section{Groundwater mitigation}

A number of discharging wells were installed along and adjacent to the new reach of Hillah River to discharge the polluted groundwater whereas the injecting wells were installed close the old reach to recharge the aquifer with fresh water as shown in Figure 10. The mitigation process represents instantaneous injectiondischarging water in and from the aquifer by the two types of wells. The process was started in January 2015 until January 2018. Fresh water of Hillah River exceeding the water demands (WD) by $20 \%$ was used to supplying the area and the same quantity $(20 \% \mathrm{WD})$ instantaneously discharged from the aquifer into the new reach of Hillah River for replenishment purposes. This dilution process was expected to refreshing the aquifer against the accumulated minerals and 
reducing their concentrations continuously as this process proceeds.

The monthly WD of Tyass was estimated and listed in (Table 2, col.1). The total water supply of old Hillah river reach was previously suggested to be (1.2WD) to satisfy the WD by existing ditches or by the injection wells. The $0.2 \mathrm{WD}$ was extracted from the aquifer by the discharging wells shown in Figure 10 and returned into the new reach of Hillah River later on. The continuous recycling of $0.2 \mathrm{WD}$ of groundwater will predominantly mitigate the aquifer water storage and reduces the chemical pollutants concentration to a minimum. Naturally, the required number of the discharging wells depends on the safe yield of the aquifer and the practical productivity of the well. However, in the case of Tyass, these constraints were not considered because of up normal flooding condition at which excessive depletion of the aquifer is not important.

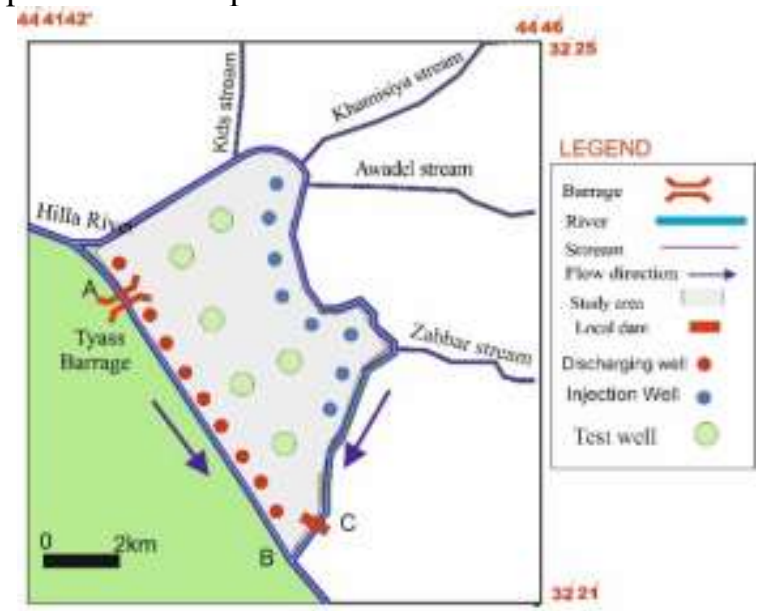

Figure 10: Discharging, injection and testing wells distribution

Table 2: Monthly WD algorithm \& actual Surface water (SW) supply

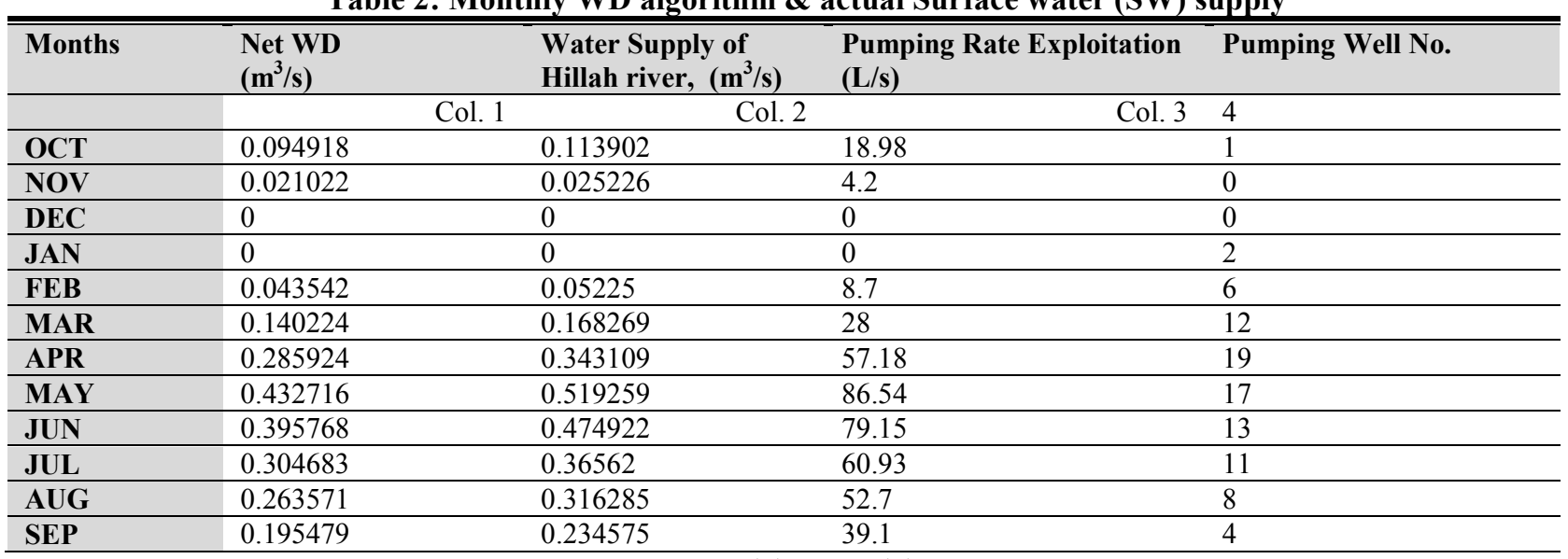

The productivity of each well: $4.6 \mathrm{~L} / \mathrm{s}, .(2)=\operatorname{Col} .(1) * 1.2, \operatorname{col}(3)=\operatorname{col}(1) * 0.2$

\section{Results and Discussions}

The pollutants concentrations values, as shown in Figures. (11a to 11f) are reduced continuously and represent the average concentrations of six testing wells scattered over the area, as shown in Figure 10. The monthly field concentration measurements were continued from January 2015 to January 2018. Since the coincidence between the estimated and measured concentrations are acceptable during 36months, the estimated values were extended to a period of 240 months ( 20 years) to reach the concentration of the added freshwater of Hillah river. All curves take a zigzag shape due to the variations of the monthly water demand discharge.

\section{Remediation of chemical pollutants impact}

Remediation of chemicals concentration in Tyass aquifer was achieved by continuous fresh water replenishment by simultaneous injecting and pumping of $0.2 \mathrm{WD}$ fresh water from Hillah river. This process was adopted and evaluated along three years. The evaluation technique was achieved by:

1- continuous field concentration measurements along 3 years of groundwater extraction and testing through the test well is shown in Figure 10.

2- Chemical pollutants concentration estimate by using the model of Eq.4.

The measured and estimated concentration values along 36 months offer an acceptable coincidence for $\mathrm{Fe}, \mathrm{Zn}, \mathrm{Cu}, \mathrm{Cd}, \mathrm{Pb}$, and TDS as represented in Figs. 11a to 11f, respectively.

3- The good coincidence between the measured and estimated pollutants concentrations of the foregoing minerals helps to prediction the concentrations for a further interval of 240 months by theoretical estimation rather than by field measurements as shown in Figure 11. 

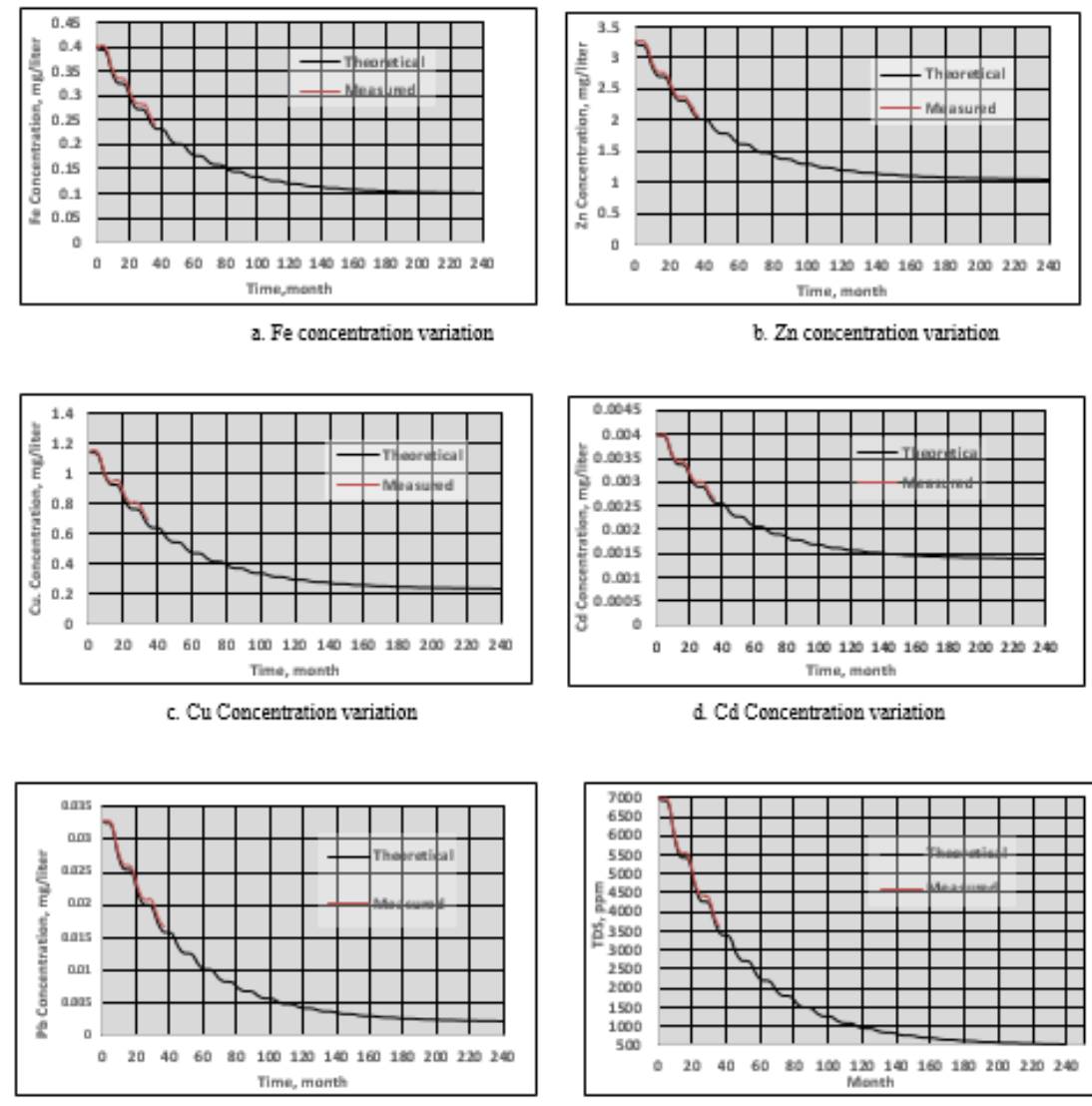

e. $\mathrm{Pb}$ concentration variation

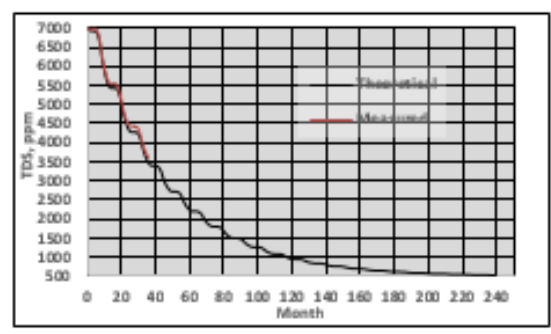

f. TDS concentration variation

Figure 11: Temporal Reduction of Pollutants Concentrations due to Measured and Theoretical Mitigation Model

\section{Reducing of Remediation Period}

It is intuitively the increase in addition of solvent volume will reduce the remediation time of chemicals concentrations, the following was done:-

1-Additions of Hillah river fresh water were doubled compared with the preceding scenario; half dilution time was obtained to reach the same final pollutants concentrations as shown in Figs $12 \mathrm{a}, 12 \mathrm{~b} \& 12 \mathrm{c}$.

2- Since concentration results were previously verified, field measurements were skipped.

\section{Conclusions and Finding}

The shallow groundwater of Tyass area is contaminated with many undesired pollutants including $\mathrm{Fe}, \mathrm{Zn}, \mathrm{Cu}, \mathrm{Cd}, \mathrm{Pb}$ and total dissolved salts (TDS) with concentrations exceed the Iraq allowable limits of (1984). The mitigation model has been successfully used to reduce the pollutants concentrations from $0.4,3.25,1.15$, 0.004 and $0.033 \mathrm{mg} / 1$ to $0.1,1.02,0.23,00.14$, $0.0021 \mathrm{mg} / 1$ for $\mathrm{Fe}, \mathrm{Zn}, \mathrm{Cu}, \mathrm{Cd}, \mathrm{Pb}$ respectively by adding $0.2 \mathrm{WD}$ of fresh water of Hillah river during a period of time 240months by using a maximum no. pumping wells of (19 at April). At the same time, the TDS was reduced from $7000 \mathrm{ppm}$ to $500 \mathrm{ppm}$ during the same period.

It is found that the mitigation model can be used for prediction of future concentrations of any pollution in heterogeneous media for specified refreshment process. 

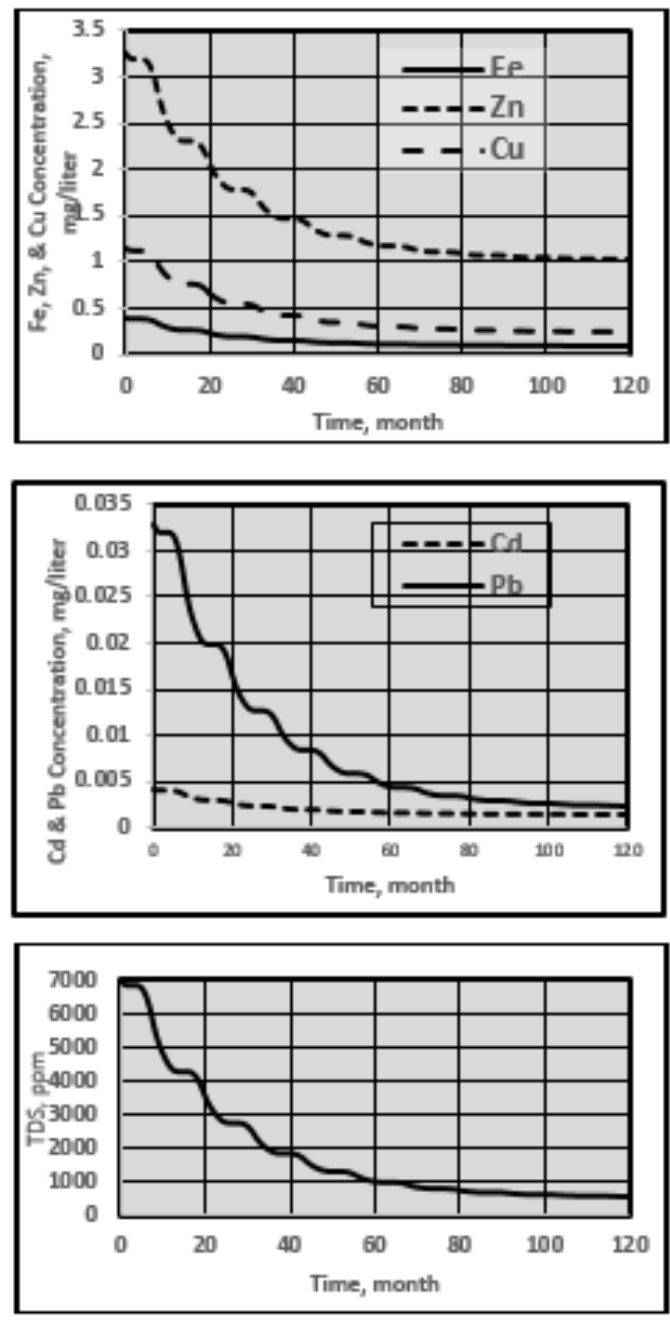

Figure 12: Temporal Reduction of Pollutants Concentrations due to Dilution Model

\section{References}

[1] M.L. Collin, A. J. Melloul, "Combined land-use and environmental factors for sustainable groundwater management," Urban Water Journal, Vol. 3, No. 3, pp. 229-237, 2001.

[2] L. V. Zuquette , O. J. Pejon, and J. Q. dos Santos, "Land degradation assessment based on environmental geoindicators in the Fortaleza metropolitan region, state of Ceará, Brazil," Journal of Environmental geology, Vol. 45, No. 3, pp. 408-425, 2004.

[3] M. J. Singleton, B.K. Esser, J.E. Moran, G.B. Hudson, W. W. McNab, and T. Harter, "Saturated Zone Denitrification: Potential for Natural Attenuation of Nitrate Contamination in Shallow Groundwater Under Dairy Operations," American Chemical Society Environmental Science Technology, Vol. 41, No. 3, pp. 759-765, 2007.
[4] A.I.A. Andrade, T.Y. Stigter, "Multi-method assessment of nitrate and pesticide contamination in shallow alluvial groundwater as a function of hydrogeological setting and land use," Agricultural Water Management Journal, Vol. 96, No. 12, pp. 1751-1765, 2009.

[5] P.R. Schwarzenbach, T. Egli, T.B. Hofstetter, U.V. Gunten, and B. Wehrli, "Global Water Pollution and Human Health," Annual Review of Environment and Resource Journal, Vol. 35, pp. 109-136, 2010.

[6] H. E. Lenny, P.T. Trang, V.M. Lan, C. Stengel, M. Amini, N.T. Ha, P. Hung Viet, and M. Berg, "Arsenic pollution of groundwater in Vietnam exacerbated by deep aquifer exploitation for more than a century," Proceedings of the National Academy of Sciences ,Vol. 108, No. 4, pp. 1246 - 1251, 2011.

[7] D. Marghade, D.B. Malpe ,and A.B. Zade," Major ion chemistry of shallow groundwater of a fast growing city of Central India," Environmental Monitoring and Assessment, Vol.184, No. 4, pp. 2405-2418, 2012.

[8] N.M.L. Al Maimuri, K.K. Ali, M.K. Hasson, "Sustainability \& Remediation of Groundwater Environment by a (Hydrogeologic Dilution) Against Radon $\left({ }^{222} \mathrm{Rn}\right)$ Pollution in Hashyimia, Iraq," International Journal of Scientific \& Engineering Research, Vol. 7, No. 6, 2016.

[9] N.M.L. Al Maimuri, M. Al Dabbas, A.R. Ali, "Environmental Sustainability of Groundwater Category under an Impact of Hashyimia Dumping Site by Using Dispersion - Advection Modeling Technology,” Baghdad,1st IJRTESS, pp. 431- 488, 2017.

[10] A.A. AL-Siddiki, "Subsurface geology of southeastern Iraq," 10th Arab Petroleum Congress, Tripoli, Libya, pp.47-49, 1978.

[11] R.M. Parsons, "Groundwater resources of Iraq (Mesopotamia plain)," Development Board Ministry of Development Government of Iraq, Vol. 11, pp. 521, 1957.

[12] T.A. Prickett, C.G. Lonngquist, "Selected Digital Computer Techniques for Groundwater Resource Evaluation," Illinois State Water Survey, Illinois, pp. 65-71, 1971.

[13] D.B. Mc Whorter, "Ground-Water Hydrology and Hydraulics," Water Resources Publications, Colorado USA, 1984.

[14] Todd, D. K, “Ground Water Hydrology," Wiley, New York, $2^{\text {nd }}$ ed., 1980.

[15] N.M.L. Al Maimuri, A.R. Ali, A. M.Hussein, K.F. Abood, A.A. Hussian, "Sustainable Management of Isolated Subsurface Heterogeneous Mediums: A Case Study in Tyass Area, Iraq," International Journal of Scientific and Engineering Research, Vol. 9, No. 4, pp. $886-898,2018$. 